\title{
Bee species decrease and increase between the 1990s and 2018 in large urban protected sites
}

\author{
Michaela M. Hofmann ${ }^{1}$. Susanne S. Renner ${ }^{1}$
}

Received: 17 November 2019 / Accepted: 10 April 2020 / Published online: 27 April 2020

(c) The Author(s) 2020

\begin{abstract}
Previous work has shown that among 428 species of bees occurring in Germany, decline or extinction over the past 40 years have been correlated with late-season emergence and restricted habitats, while other factors, such as pollen specialization, body size, nesting sites, and sociality, played no role in models that included a phylogeny of these bees. Doing best are springflying, city-dwelling species. Building on these results, we here investigate changes in bee diversity from the 1990s to 2018 at three protected sites within the city perimeter of Munich, focusing on the correlates of flight season (spring or summer), flight duration (in months), and number of habitats (one or two vs. three to six). Local species pools were assessed against the total species pool from 1795 onwards. Twenty years ago, 150 species were present at one or more of the sites, while in 2017/2018, this was true of 188 species, with the increase at two sites being of similar proportion. In two of the three areas, broad habitat use was positively correlated with persistence. Flight season or duration had no statistical effect. These results underscore the function of urban protected sites in bee conservation and imply that summer food shortages, which negatively affect bees in agricultural areas, play no role in urbanized regions so that late-season flight is not an extinction handicap.
\end{abstract}

Keywords Apidae $\cdot$ Bee faunas $\cdot 20$-year monitoring $\cdot$ Seasonal flight time $\cdot$ Urban nature conservation

\section{Introduction}

If the current rate of urbanization stays unchanged, models predict an increase in urban land cover by 1.7 million $\mathrm{km}^{2}$ by 2050 , which would be approximately 1.4 times the area of 2012 (Zhou et al. 2019). Urbanization commonly is accompanied by surface sealing, reduced foraging and nesting sites for animals, light pollution, dense traffic, and other anthropogenic stressors. It therefore reduces species richness and evenness for most biotic communities (Grimm et al. 2008; Hernandez et al. 2009). However, the degree of urbanization within cities varies, and studies have found high small-scale heterogeneity, providing conservation opportunities (Baldock et al. 2019). This may be especially true for animals

Electronic supplementary material The online version of this article (https://doi.org/10.1007/s10841-020-00238-y) contains supplementary material, which is available to authorized users.

Susanne S. Renner

renner@1mu.de

1 Systematic Botany and Mycology, Department of Biology, University of Munich (LMU), Menzinger Straße 67, 80638 Munich, Germany with small habitat ranges, such as arthropods. In the present study, we focus on bees, whose decline in European agricultural areas has been linked to parasites, pesticides, and lack of flowers (Goulson et al. 2015; Seibold et al. 2019).

Germany harbours some 561 species of bees of which 557 have been assessed for successive Red Lists over the past 40 years; in 2011, 228 (41\%) species in Germany were categorized as threatened and 39 as already extinct (Westrich et al. 2011). An earlier analysis of the extrinsic or intrinsic parameters that might predict the decline or extinction of these species focused on the 428 species with the most complete data (Hofmann et al. 2019). The analysed intrinsic traits were pollen specialization, body size, nesting sites (above ground or below ground; other bee nests), sociality, duration of flight activity (weeks or months), and flight season (spring or summer). The extrinsic parameters consisted of habitat type and altitudinal range. The study used a molecular phylogeny that included all scored species and applied Bayesian Hierarchical modelling so that all predictors could be analysed simultaneously. Only three parameters statistically predicted extinction risk over the 40 years, namely habitat breadth, duration of flight activity, and-surprisingly_flight season. Early-flying bees have a three times 
lower extinction probability than late-flying ones. Also, species restricted to non-urban habitats were about three times more likely to go extinct than city-dwelling species. This matches a seasonal gap in nectar availability in European farmland in August and September (Timberlake et al. 2019).

We here test these results with more fine-grained data from three large green spaces in the city of Munich. By the 1990s, a total of 324 species had been recorded for Munich, and between 1997 and 2017, the city still had about 232 species (Hofmann and Renner, 2020). We expected that the steady seasonal availability of nectar and pollen in city gardens, allotments, parks, and balconies would mean that early or late seasonal flight would not be correlated with bee declines over the past 20 years, while habitat breadth might still influence bee species persistence because the city overall, as well as our three study sites, offer much spatial heterogeneity and a range of habitats.

\section{Materials and methods}

\section{Study sites, species and their scored traits}

Figure 1 shows the location of the three study sites within Munich (Bavaria, Germany). Since 1795, 324 species have been recorded from Munich (Appendix S1). The first study site, the Allacher Lohe, is a heath and forest area located at $48.2025^{\circ} \mathrm{N}, 11.4812^{\circ} \mathrm{E}$. In 1988, a marshalling yard was constructed in this area, which has now been in operation since 1991. The remaining 150 ha area of the Allacher Lohe became a nature reserve on 1 April 2000. The second site, the Virginia Depot, is located in the Munich-Lerchenau suburb $\left(48.1973^{\circ} \mathrm{N}, 11.5613^{\circ} \mathrm{E}\right)$ and comprises about 20 hectares. From 1945 until 1957, the depot was owned by the US army, which used it as the Virginia Area Storage Facility. Between 1957 and the 1990s, the German army took it over, and since 2003, it has been managed by a regional nature conservation group and been transformed into a city biotope. Since the depot was off-limits between 1945 and 2003, it harbours rare plants and animals. Our third site, the Munich Botanical Garden, was opened in May 1914 and has a size
Fig. 1 The location of the study sites within the Munich city perimeter. For scale, the distance from the Munich Botanical Garden to the Virginia Depot is $8 \mathrm{~km}$

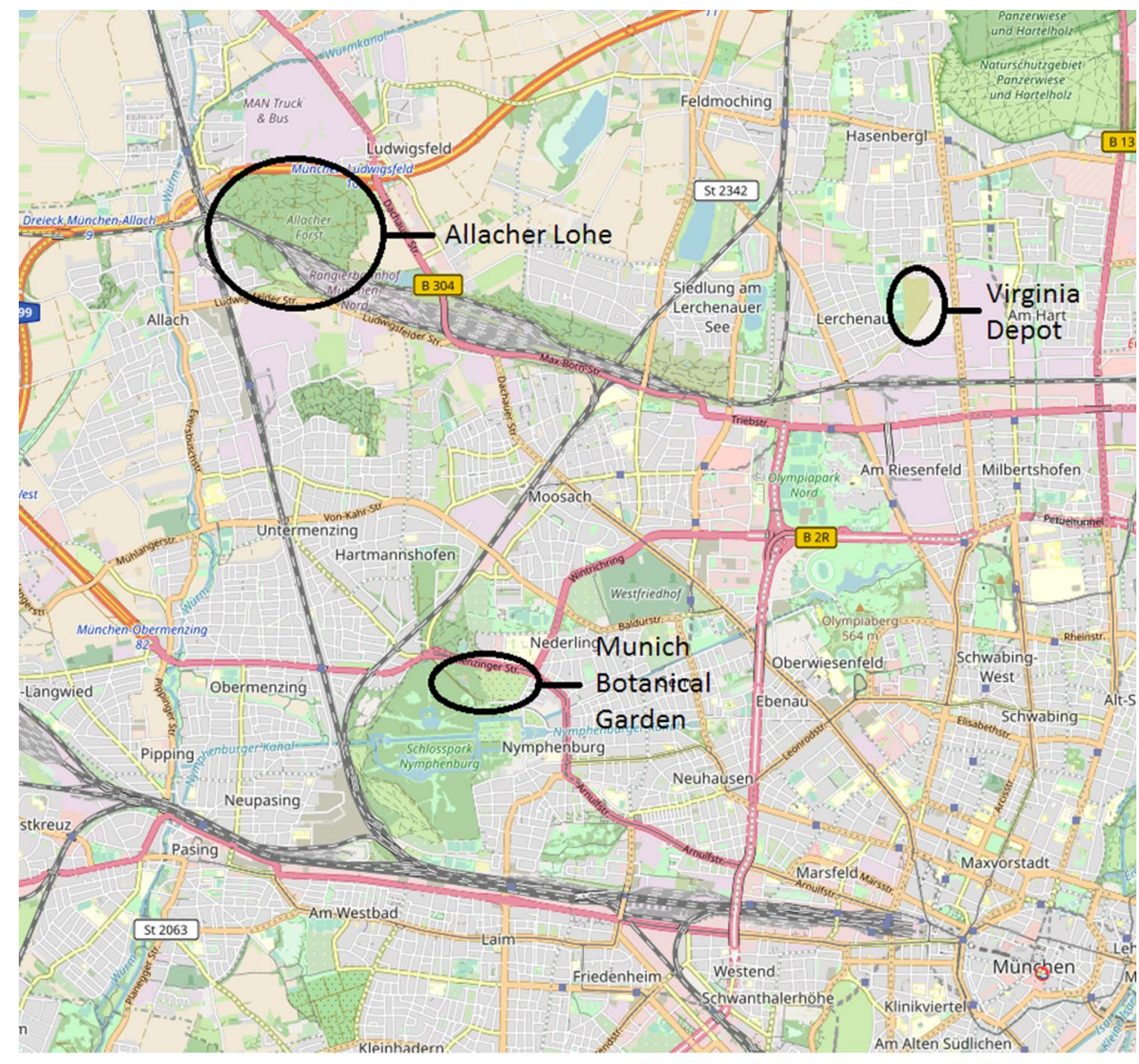


of about 20 ha (Hofmann et al. 2018). Its layout of paths and beds is protected as a cultural monument. The garden's outdoor area harbours thousands of native and non-native species and subspecies (data from the garden's living plant database, accessed by the second author), and it is flowerrich from late February to October.

Besides listing species names, taxonomic authors, and bee family, Appendix S1 also provides data on eight intrinsic or extrinsic factors for the 324 species, namely Red List status, diet width (oligolectic, polylectic, unknown, cuckoo), pollen collecting mode (leg, pollen brush, etc.), nesting site, flight months, flight season, number of habitats occupied, and 'habitat breadth', coded based on the number of habitats occupied (all from Hofmann et al. 2019). Narrow habitat breadth was defined as occurrence in one or two of six habitats: (i) forests and heaths; (ii) meadows; (iii) hedgerows; (iv) wasteland and nutrient-poor sites; (v) raw-soil sites with little vegetation, such as sand dunes, heathland, steppes, and sand or gravel pits; and (iv) urban areas, including gardens and parks. Broad habitat use was defined as occurrence in three to six habitats. Species with unknown habitat preferences were excluded from further analysis.

\section{Historic and 2017/2018 monitoring of the three sites}

The Allacher Lohe and adjoining areas were first monitored between April and September 1980 (Warncke 1982) when 97 species were recorded. This first species list was augmented by J. Schuberth during several monitoring walks between 1990 and 1999, bringing the number up to 135 species. Twenty years later, in 2009 and 2010, Schuberth and Dubitzky recorded 106 species for the area. The first author transcribed all these reports, which are cited in the footnote of Appendix S1, in the nature conservancy's office in Munich because they may not be copied and distributed. For the Virginia Depot, monitoring was conducted during the flight season of 1998 and 1999, again by Schuberth, and it, too, was transcribed by the first author in the Bavarian nature conservancy's office in Munich. The bees of the Munich Botanical Garden were surveyed in 1997/1999 by Bembé et al. (2001) and in 2015/2017 by Hofmann et al. (2018).

Between March 2017 and August 2018, the first author visited the Allacher Lohe and the Virginia Depot once a month (Appendix S2 shows the dates). For the Allacher Lohe, the parts north and south of the marshalling yard were visited on consecutive days. Monitoring walks were conducted between 10 a.m. and 4 p.m. on sunny, warm days with little or no wind. The mapping did not follow a strict route; instead, bees were searched for on flowers and at likely nesting sites. Where possible, species were identified directly in the field and documented via macro-photography in a standardized setup: for close-up pictures, the bees were caught with an insect net and cooled down for $10 \mathrm{~min}$ in an Eppendorf cupped plastic vial stored on ice in a cooled box. When the bees fell into cold rigor, they were transferred onto scale paper (using a small box lined with millimetre paper on its bottom) and photographed from all sides (SLR camera: Pentax K-x; Lens: Sigma DG 17-70 mm, 1:2.8, macro). Within one to two minutes, they warmed up again and were released at the location where they had been caught. For species that are taxonomically difficult to distinguish by morphology alone, such as members of Sphecodes, Lasioglossum and Halictus, voucher specimens, preferably males (for identification by genitalia preparations), were collected and identified morphologically and via DNA barcoding (methods and primers as described in Hofmann et al. 2018). Voucher specimens have been deposited in the Munich zoological collections (acronym ZSM). Photo vouchers are accessible at the Diversity Workbench server (DWB; https://diversityworkbench.net/Portal/DiversityWorkbench), and DNA barcodes at NCBI GenBank (https://www.ncbi.nlm. nih.gov/genbank/). See Appendix S2 for accession numbers.

\section{Statistical analyses and data structure}

Our earlier study of predictors of changes in German bee diversity over the past 40 years relied on phylogeneticallyinformed models, but no phylogenetic signal in the prediction of species' vulnerability was detected (Hofmann et al. 2019: Fig. S5). We therefore here use simple logistic regression with two models applied to the 324 species recorded for Munich since 1795 , scoring them as 0 , if they were not present in one or more of the study areas, or as 1 if present (Appendix S1). Model 1 included duration of flight time in months ("flight duration') as a linear predictor while model 2 instead included flight season ('seasonality', with spring defined as February to May and summer defined as June to September) as a categorical predictor, with the categories 'early', covering spring (found in $\mathrm{n}=19$ of the 324 species), and 'late', covering summer ( $n=66$; Appendix S1 shows all sources). Species active in parts or all of spring and summer were categorized as 'intermediate' $(\mathrm{n}=239)$. Presence at time zero $(T 0$, the 1990s) and habitat breadth, with the categories 'narrow' and 'broad', were included in both models.

Model 1 had the form:

Occurrence $_{i} 1 \sim \operatorname{Bernoulli}\left(p_{i}\right)$

$\begin{aligned} \log i t\left(p_{i}\right)= & \alpha+\beta_{1} * \text { OccurrenceT } 0+\beta_{2} * \text { Habitat.breadth } \\ & +\beta_{3} * \text { Flight.duration }\end{aligned}$

Model 2 had the form:

Occurrence $_{i} 1 \sim \operatorname{Bernoulli}\left(p_{i}\right)$ 


$$
\begin{aligned}
\log i t\left(p_{i}\right)= & \alpha+\beta_{1} * \text { OccurrenceT } 0+\beta_{2} * \text { Habitat.breadth } \\
& +\beta_{3} * \text { Seasonality }
\end{aligned}
$$

Predicted occurrence was defined as predicted probability $>0.5$. Model accuracy was calculated as (true positives + true negatives)/total pool. All statistical analyses were conducted in R 3.6.1 (R Core Team 2019).

\section{Results}

Twenty years ago, 150 species were present at one or more of the sites, while in 2017/2018, this was true of 188 species, with the species increase at two sites being of similar proportion (Tables 1 and 2). Habitat breadth had a slight positive influence on species persistence when the three sites were analysed together, while flight season (February to May versus June to September) had no statistical effect on persistence (Fig. 2a; Table S1 in Appendix 3). When the analysis was run separately for each site, habitat breadth no longer explained persistence of species at the Virginia Depot (Fig. 2a). Using flight season (early, late, or intermediate) instead of flight duration (in months), yielded similar results (Fig. 2b; Table S1 in Appendix 3). The flight duration model correctly predicted the occurrence of $77 \%$ of the 319 species after 20 years (T1), while the flight season model had an accuracy of $76 \%$ (Table S2 in Appendix 3).

\section{Discussion}

At two of the three sites, the ability to live (nest and forage) in more than two habitats was strongly positively correlated with species' persistence over the 20 years from the 1990 s to 2017/2018, while at the third site, the Virginia Depot, habitat breadth was not correlated with local extinction probability
Table 2 Numbers of species at the study areas Allacher Lohe, Virginia Depot, and Botanical Garden

\begin{tabular}{lrcl}
\hline Number of species & Allacher Lohe & Virginia Depot & $\begin{array}{l}\text { Munich } \\
\text { Botanical } \\
\text { Garden }\end{array}$ \\
\hline Present in 1990s & 135 & 32 & 78 \\
Absent in 1990s & 189 & 292 & 246 \\
Present in 2017/2018 & 80 & 44 & 105 \\
Absent in 2017/2018 & 244 & 280 & 219 \\
\hline
\end{tabular}

The location of the study sites is shown in Fig. 1

(Fig. 2). Flight season and duration of flight activity were uncorrelated with species persistence, matching our expectation that cities offer pollen and nectar throughout the season. The apparent absence of seasonal food scarcity, however, needs to be interpreted with care because we used bee flight months as given in the literature (Appendix S1). Bees' flight times vary between years and regions, depending on local conditions, and ideally, one would therefore use flight times from the Munich area and particular monitoring years. Such data, however, are not available for most of the 324 species.

The number of species at the Virginia Depot has increased from 32 to 44 and that in the Munich Botanical Garden from 78 to 105 over essentially the same 20-year period (Table 2), while in the Allacher Lohe, the number of bee species has decreased from 135 in the late 1990s to 80 in 2018. The marshalling yard in the Allacher Lohe, which has been in continuous operation since 1991, may be contributing to the decline in species at this site. A case in point is Andrena rufizona, which had one of its largest known populations in Germany in Allach before the marshalling yard opened, but declined from about 20 breeding females to one female and several males by 1999 . The last sighting of this species was in 2002 (J. Schuberth, Munich, personal communication to the first author, 2019).

\begin{tabular}{|c|c|c|c|c|c|c|c|}
\hline \multicolumn{4}{|c|}{ Present in $2017 / 2018$} & \multicolumn{4}{|c|}{ Absent at $2017 / 2018$} \\
\hline & Early & Late & Intermediate & & Early & Late & Intermediate \\
\hline \multicolumn{8}{|c|}{ Present in 1990s } \\
\hline Broad & 5 & 12 & 76 & Broad & 0 & 7 & 22 \\
\hline Narrow & 1 & 7 & 4 & Narrow & 1 & 6 & 9 \\
\hline \multicolumn{4}{|c|}{ Present in $2017 / 2018$} & \multicolumn{4}{|c|}{ Absent at $2017 / 2018$} \\
\hline & Early & Late & Intermediate & & Early & Late & Intermediate \\
\hline \multicolumn{8}{|c|}{ Absent in 1990s } \\
\hline Broad & 2 & 3 & 11 & Broad & 2 & 9 & 51 \\
\hline Narrow & 0 & 2 & 13 & Narrow & 8 & 19 & 49 \\
\hline
\end{tabular}

Table 1 Numbers of species at the three study areas with an early, late, or intermediate flight season and a narrow or broad habitat breadth

The total number of bee species was 319. The location of the study sites is shown in Fig. 1 and the scorings for flight season and habitat breath in Appendix S1; also, "Materials and methods" 
(a)

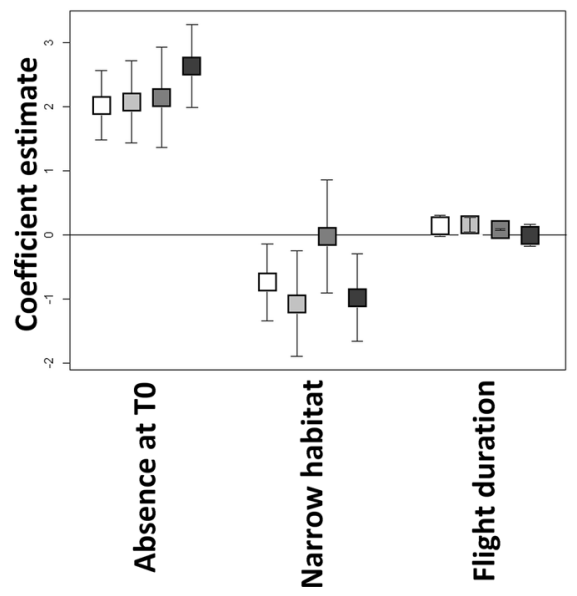

Fig. 2 Coefficient estimates (beta estimate $+95 \%$ confidence intervals) for the effects of a occurrence at time zero (T0, the 1990s), habitat breadth, and flight duration (in months) or $\mathbf{b}$ occurrence at $\mathrm{T} 0$, (b)



$\square$ All sites

$\square$ Allacher Lohe

$\square$ Virginia Depot

Botanical Garden
At the other two sites, the Virginia Depot and the Botanical Garden, species diversity over the past 20 years has increased in similar proportion (Table 2). Winters in Munich have become shorter by 4 weeks over the past 100 years (Zohner and Renner 2014), and warmer springs and summers have led to a significant increase in particular plant and insect species, including fig trees, which now establish spontaneously, and various species of Mediterranean Echium. Some species of bees are currently expanding their ranges in southern Germany, including Anthidiellum strigatum, Anthophora bimaculata, Eucera nigrescens, Halictus scabiosae, Halictus subauratus, Hoplitis adunca, Osmia cornuta, and Xylocopa violacea (Hofmann et al. 2018). Other studies of bee diversity in European cities also are reporting high diversities (Banaszak-Cibicka et al. 2018: Poznan, Poland), with the urban core of Northampton even having more species than surrounding meadows (Sirohi et al. 2015).

\section{Limitations of our study}

A trait of particular interest to have included would be bees' preferences for warm or cool habitats. Cities provide a disproportionate diversity of warm, open habitats, including on green roofs (Hofmann and Renner 2018), while cool habitats are probably underrepresented in cities. Another severe limitation of our analysis is the uneven sampling effort over space and time, with the various observers having different taxonomic expertise. We therefore cannot plot the cumulative number of species recorded in particular habitats within Munich as a function of the cumulative effort expended searching for them because we do not know the man-hours spent nor the numbers of bees seen and how this relates to habitat breadth (one or two vs. three to six), and flight season (early, late, intermediate) on species occurrence by 2017/2018 (T1). Positive estimates correspond to an increased probability of occurrence at T1 the numbers of bee species discovered. Lastly, our study is limited to only three focal areas (the Botanical Garden, the Allacher Lohe, and the Virginia Depot), so that we have almost no statistical power to link bee species persistence or loss to bees' intrinsic and extrinsic traits, such as flight season or habitat breadth.

Our results nevertheless highlight the importance for bee conservation of protected urban sites. As long as such sites include heterogeneous habitats, bee populations appear to do well in them. This is helped by most European bees being small, with correspondingly small foraging ranges (Gathmann and Tscharntke 2002; Greenleaf et al. 2007; Zurbuchen et al. 2010; Hofmann et al. in review), a trait that on the one hand enables bees to maintain populations in small areas, on the other must make them vulnerable to cityscape fragmentation.

Acknowledgements Open Access funding provided by Projekt DEAL. We thank Markus Bräu (Munich City Department of Health and Environment) and Johannes Schuberth (Munich) for sharing their data, two anonymous reviewers for comments on the manuscript, and L. Marchioro and Professor H. Küchenhoff of the StaBLab of the LudwigMaximilians-University for statistical advice.

\section{Compliance with ethical standards}

Conflict of interest There are no conflicts of interest by any author.

Open Access This article is licensed under a Creative Commons Attribution 4.0 International License, which permits use, sharing, adaptation, distribution and reproduction in any medium or format, as long as you give appropriate credit to the original author(s) and the source, provide a link to the Creative Commons licence, and indicate if changes were made. The images or other third party material in this article are included in the article's Creative Commons licence, unless indicated otherwise in a credit line to the material. If material is not included in 
the article's Creative Commons licence and your intended use is not permitted by statutory regulation or exceeds the permitted use, you will need to obtain permission directly from the copyright holder. To view a copy of this licence, visit http://creativecommons.org/licenses/by/4.0/.

\section{References}

Baldock KC, Goddard MA, Hicks DM, Kunin WE, Mitschunas N, Morse H, Staniczenko PP (2019) A systems approach reveals urban pollinator hotspots and conservation opportunities. Nat Ecol Evol 3:363-373

Banaszak-Cibicka W, Twerd L, Fliszkiewicz M, Giejdasz K, Langowska A (2018) City parks vs. natural areas-is it possible to preserve a natural level of bee richness and abundance in a city park? Urban Ecosyst 21:599-613

Bembé B, Gerlach G, Schuberth J, Schönitzer K (2001) Die Wildbienen im Botanischen Garten München. Nachrichtenblatt der bayerischen Entomologen 50:30-41

Gathmann A, Tscharntke T (2002) Foraging ranges of solitary bees. J Anim Ecol 71:757-764

Goulson D, Nicholls E, Botías C, Rotheray EL (2015) Bee declines driven by combined stress from parasites, pesticides, and lack of flowers. Science 347:1435. https://doi.org/10.1126/science.12559 57

Greenleaf SS, Williams NM, Winfree R, Kremen C (2007) Bee foraging ranges and their relationship to body size. Oecologia 153:589-596

Grimm NB, Faeth SH, Golubiewski NE, Redman CL, Wu J, Bai X, Briggs JM (2008) Global change and the ecology of cities. Science 319:756-760

Hernandez JL, Frankie GW, Thorp RW (2009) Ecology of urban bees: a review of current knowledge and directions for future study. Cities Environ (CATE) 2:1-15

Hofmann MM, Renner SS (2018) Bee species recorded between 1992 and 2017 from green roofs in Asia, Europe, and North America, with key characteristics and open research questions. Apidologie 49:307-313

Hofmann MM, Renner SS (2020) One-year-old flower strips already support a quarter of a city's bee species. J Hymenoptera Res. 75:87-95. https://doi.org/10.3897/jhr.@@.47507

Hofmann MM, Fleischmann A, Renner SS (2018) Changes in the bee fauna of a German botanical garden between 1997 and 2017, attributable to climate warming, not other parameters. Oecologia 187:701-706

Hofmann MM, Zohner CM, Renner SS (2019) Narrow habitat breadth and late-summer emergence increase extinction vulnerability in Central European bees. Proc R Soc B 286:20190316

Hofmann MM, Fleischmann A, Renner SS (2020) Foraging distances in six species of solitary bees with body lengths of 6 to $15 \mathrm{~mm}$, using individual tagging, suggest $150 \mathrm{~m}$-rule-of-thumb for flower strip distances. J Hymenopt Res (in review)

R Core Team (2019) R: a language and environment for statistical computing. R Foundation for Statistical Computing, Vienna, Austria. https://www.R-project.org/

Seibold S, Gossner MM, Simons NK, Blüthgen N, Müller J, Ambarlı D, Linsenmair KE (2019) Arthropod decline in grasslands and forests is associated with landscape-level drivers. Nature 574:671-674

Sirohi MH, Jackson J, Edwards M, Ollerton J (2015) Diversity and abundance of solitary and primitively eusocial bees in an urban centre: a case study from Northampton (England). J Insect Conserv 19:487-500

Timberlake TP, Vaughan IP, Memmott J (2019) Phenology of farmland floral resources reveals seasonal gaps in nectar availability for bumblebees. J Appl Ecol 56:1585-1596

Warncke K (1982) Die Trockenrasen vor dem Südrand des Allacher Forstes (München), ein ausgefallender Biotop für seltene Wildbienenarten. Nachrichtenblatt der Bayerischen Entomologen 31:1-3

Westrich P, Frommer U, Mandery K, Riemann H, Ruhnke H, Saure C, Voith J (2011) Rote Liste und Gesamtartenliste der Bienen (Hymenoptera, Apidae) Deutschlands. Naturschutz und Biologische Vielfalt 70:373-416

Zhou Y, Varquez AC, Kanda M (2019) High-resolution global urban growth projection based on multiple applications of the SLEUtH urban growth model. Sci Data 6:34

Zohner CM, Renner SS (2014) Common garden comparison of the leaf-out phenology of woody species from different native climates, combined with herbarium records, forecasts long-term change. Ecol Lett 17:1016-1025

Zurbuchen A, Bachofen C, Müller A, Hein S, Dorn S (2010) Are landscape structures insurmountable barriers for foraging bees? A mark-recapture study with two solitary pollen specialist species. Apidologie 41:497-508

Publisher's Note Springer Nature remains neutral with regard to jurisdictional claims in published maps and institutional affiliations. 